\title{
Phytoconstituents and bioactivities of the bark of Pleiogynium timorense (DC.) Leenh (Anacardiaceae)
}

\author{
Gehan Fawzy Abdel Raoof ${ }^{*}{ }^{\mathbb{D}}$, Ataa Abdelhaleem Said ${ }^{1}$, Khaled Younes Mohamed ${ }^{2}$, Hesham A. Gomaa $^{3,4}$ \\ ${ }^{1}$ Pharmacognosy Department, National Research Centre, Dokki, Giza, Egypt \\ ${ }^{2}$ Internal Medicine Department, Medical Division, National Research Centre, Giza, Egypt \\ ${ }^{3}$ Biochemistry Department,Faculty of pharmacy, Nahda university ,Beni-Suef, Egypt \\ ${ }^{4}$ Pharmacology Department, College of Pharmacy, Jouf University, Sakakah, Saudi Arabia
}

\section{A R T I C L E I N F O}

Article Type:

Original Article

Article History:

Received: 13 February 2019

Accepted: 2 June 2019

Keywords:

Antihyperglycaemic agents

Antioxidant

Cytotoxic activity

Hepatorenal toxicity

Phenolic compound

Pleiogynium

\begin{abstract}
A B S T R A C T
Introduction: The purpose of this study was to evaluate the phytoconstituents and various bioactivities of Pleiogynium timorense bark as a step towards the production of a new drug from natural origin to overcome the complications of the synthetic drugs.

Methods: The phenolic compounds were isolated and identified by chromatographic and spectroscopic methods as ultra violet (UV) and nuclear magnetic resonance (NMR) spectra. The isolated compounds, as well as $70 \%$ methanol extract of $P$. timorense bark were tested for cytotoxicity against human colon carcinoma (HCT 116), human hepatocellular liver carcinoma (HepG2), normal melanocytes (HFB-4) and human breast carcinoma (MCF-7) cell lines. In addition, the methanol extract was evaluated for renal protective, hepatoprotective, antioxidant and antihyperglycaemic activities.

Results: Seven phenolic compounds were isolated from the bark of the plant for the first time which were identified as; pyrogallol, catechin, gallic acid, kaempferol, quercetin, rutin and quercetrin. Moreover, the methanol extract of the bark showed a promising cytotoxic effect against HepG2 cell line more than that of the isolated compounds comparing with doxorubicin (a positive control), where catechin and gallic acid showed moderate effects. In addition, the methanol extract showed potent antioxidant, hepatorenal protective and antihyperglycaemic effects.

Conclusion: Pleiogynium timorense extract possesses a potent cytotoxic effect against HepG2 cell line and significant antioxidant, hepatorenal protective and antihyperglycaemic effects.
\end{abstract}

\section{Implication for health policy/practice/research/medical education:}

The results of this study suggest that the methanol extract of Pleiogynium timorense bark, as well as catechin and gallic acid can be used as promising cytotoxic agents against HepG2 cell line. Moreover, the methanol extract can be used as a potent antioxidant, hepatorenal protective and antihyperglycaemic agent upon further clinical studies.

Please cite this paper as: Abdel Raoof GF, Said AA, Mohamed KY, Gomaa HA. Phytoconstituents and bioactivities of the bark of Pleiogynium timorense (DC.) Leenh (Anacardiaceae). J Herbmed Pharmacol. 2020;9(1):20-27. doi: 10.15171/jhp.2020.03.

\section{Introduction}

The production of drugs from plant origin aims to avoid the complications of synthetic origin agents. Pleiogynium timorense (DC.) Leenh. (Anacardiaceae) is native to Australia, with the common name of Gambozia and is described as an ornamental tree $(1,2)$. Anacardiaceae contains many plants with edible seeds and fruits (e.g., Cashew nuts, Pistachio nuts and mango (3). The fruits of P. timorense (DC.) Leenh. can be eaten and used in making jams and jellies (4). Rutin, myricetin, hyperin, quercitrin, quercetin, $\beta$-sitosterol and lupeol have been isolated from the leaves which possessed potent antimicrobial effects against Staphylococcus aureus and Bacillus subtilis (5). Another study showed that the alcoholic extract of the leaves had antioxidant, anti-inflammatory and hypoglycemic effects. Moreover, myricetin-3-O-a-L-rhamnopyranosid, kaempferol, kaempferol-3-O- $\beta$-D-glucopyranoside, quercetin $\quad-3-O-\beta$-D-glucopyranoside $1,3,4,6$-tetra- $O$ galloyl- $\beta$-D-glucopyranose, $\quad 1,4,6$-tri- $O$-galloyl- $\beta$-Dglucopyranose, 3,5-di-O-galloylquinic acid,quercetin3-O- $\beta$-D-galactopyranoside, gallic acid, kaempferol-3$O-\beta-\mathrm{D}-6$ "-methyl glucuronopyranoside, kaempferol3-O- $\beta$-D-galactopyranoside and kaempferol-3-O- $\beta$-Dglucuronopyranoside were isolated and identified from

*Corresponding author: Gehan Fawzy Abdel Raoof,

Email: ahmedkhaled_1@hotmail.com 
the leaves of the plant (6). Cyanidin-3-glucoside was isolated from Pleiogynium fruits which showed a potent antioxidant activity (7). In our previous work, rutin, catechin, quercetrin and quercetin were isolated from the pericarp of the plant, as well as the methanol extracts of the pericarp and seeds and showed anti-inflammatory, antioxidant, analgesic, hepatorenal protective effects (8). Moreover, GC/MS analysis of the lipoidal matter of the seeds showed that 1-heptene was the major compound in unsaponifiable matter, while linoleic acid was the major fatty acid (9). Furthermore, dichloromethane extract of the bark showed a significant activity against the A2780 human ovarian cancer cell line due to the presence of three new trihydroxy alkylcyclohexenones which were isolated from this extract (10). In our recent work the constituents of $P$. timorense pericarp and seeds were identified by using high-performance liquid chromatography (HPLC) with electrospray ionization mass spectrometry (11). Moreover, the volatile constituents of $P$. timorense fruits were identified which showed a moderate cytotoxic effect on human hepatoma cells and a powerful cytotoxic effect against laryngeal carcinoma and breast adenocarcinoma human tumor cell lines (12). The present study aims to the methanol extract of the bark of this plant as antioxidant, antihyperglycaemic, cytotoxic and hepatorenal protective agent with the aim of producing a natural drug.

\section{Materials and Methods}

Equipments, materials and chemicals

Solvent mixtures; $\mathrm{S}_{1}$ : BAW (n-butanol: acetic acid: water (4:1:5, v/v/v) upper phase), $S_{2}$ : (water: glacial acetic acid $(85: 15, \mathrm{v} / \mathrm{v})$ ) and $\mathrm{S}_{3}$ : (methanol: chloroform (30:70)). Thin layer chromatography (TLC) was done on TLC silica gel $\mathrm{F}_{254}$ plates (200 mm layer thickness) (Merck; Darmstadt, Germany), column chromatography was done on Silica gel $(0.063-0.200 \mathrm{~mm})$ and Sephadex LH-20 (Pharmacia Fine Chemicals). Nuclear magnetic resonance (NMR) spectra were measured on JEOL EX-500 spectrometer (Tokyo, Japan) with $500 \mathrm{MHz}$ for ${ }^{1} \mathrm{H}-\mathrm{NMR}$ and $125 \mathrm{MHz}$ for ${ }^{13} \mathrm{C}-\mathrm{NMR}$. MS was done using Finnigan MAT SSQ 7000, $70 \mathrm{eV}$. Ultraviolet spectra were recorded by using UV/VIS: Shimadzu UV, chromatograms were visualized under visible recording spectrophotometer model-UV 240 (NRC, Egypt).

Plant identification and collection

The bark of $P$. timorense was prepared from Zoo garden, Giza, Egypt. The plant was identified by Dr. M. El-Gebaly, the taxonomist at the Department of Botany, National Research Centre (NRC), Giza, Egypt. A voucher specimen (possessing number 2001) was kept in NRC.

Phytochemical screening

The constituents of the methanolic extract of the bark were identified by standard procedures as previously described $(13,14)$.

HPLC determination of phenolics and flavonoids The identification and quantification of flavonoids and phenolics in $70 \%$ methanol extract of $P$. timorense bark were performed by HPLC according to the previously described methods $(15,16)$.

\section{Extraction and isolation}

The air dried powdered bark of $P$. timorense $(1 \mathrm{~kg})$ was extracted with petroleum ether $\left(60-80^{\circ} \mathrm{C}\right)$ for defatting. The defatted powder was extracted with $70 \%$ methanol by percolation, then the concentrated extract (70 g) was phytochemically screened using the standard procedures which were previously described (13) to identify its constituents. The extract ( $40 \mathrm{~g}$ ) was subjected to polyamide CC and eluted with gradient water: methanol (10:0) to $(0: 10)$ to give five fractions. Fraction 1 , one compound which was eluted with water: methanol (90:10), was purified on Sephadex LH-20 CC and was eluted with methanol to give compound 1. Fraction 2, two compounds which were eluted with water: methanol (80:20), was applied on Sephadex LH-20 C using methanol as eluent to give compounds 2 and 3. Fraction 3, two compounds which were eluted with water: methanol (70:30), was applied on Sephadex LH-20 C to give compounds 4 and 5. Fraction 4, one compound which was eluted with water: methanol (60:40), was purified on Sephadex LH-20 C to give compound 6. Fraction 5, one compound which was eluted with water: methanol (50:50), was purified on Sephadex LH-20 C to give compound 7.

\section{Cytotoxicity assay procedures}

\section{Human tumor cell lines}

Human breast carcinoma (MCF-7), normal melanocytes (HFB-4), human hepatocellular liver carcinoma (HepG2) and human colon carcinoma (HCT116) cell lines were obtained from the American Type Culture Collection and were maintained by serial sub-culturing in the National Cancer Institute, Cairo, Egypt.

\section{Culture media}

The cells were suspended in RPMI 1640 medium (SIGMA ALORICH) supplemented with $10 \%$ fetal calf serum (SIGMA, USA) in presence to $1 \%$ antibiotic antimycotic mixture $(10.000 \mathrm{U} / \mathrm{mL}$ K-penicillin, $10.000 \mu \mathrm{g} / \mathrm{mL}$ streptomycin sulphate and $25 \mu \mathrm{g} / \mathrm{mL}$ amphotericin B) and 1\% L-glutamine (all purchased from Lonza, Belgium).

\section{Assay method for cytotoxic activity}

The cytotoxicity against HCT116, Hep-G2, HFB4 and MCF-7 cells were tested in the National Cancer Institute, according to the SRB (Sulforhodamine B) assay using MTT (3-(4,5-dimethylthiazol2-yl)- 2,5-diphenyltetrazolium bromide) method using Adriamycin ${ }^{\circledR}$ (Doxorubicin) 10 
mg vials (Pharmacia, Sweden) as the reference drug, the method was previously described by (17).

\section{Animals}

Sprague Dawley rats (130-150 g) were selected and kept in the controlled environmental conditions with free access to water and diet. The handlings with animals were complied with the ethical guidelines of the Medical Ethical Committee of the National Research Centre in Egypt and in accordance with the guidelines of the International Association for the Study of Pain Committee for Research and Ethical Issues.

Acute toxicity study

The $\mathrm{LD}_{50}$ of methanol (70\%) extract of $P$. timorense bark was determined using Karber method that was previously described (18).

Antioxidant, hepatoprotective, and renal-function protective effects

Rats were classified into normal and damaged liver (received carbon tetra chloride $\left(\mathrm{CCl}_{4}\right)$ ) groups. Each group was classified into 4 different groups ( 4 rats in each); group 1 (control) received distilled water; group 2 received silymarin (50 mg/kg), while groups 3 and 4 received 150 and $300 \mathrm{mg} / \mathrm{kg}$ tested extract of $P$. timorense, respectively, for 15 days. At the end of experimental period, the rats were anaesthetized as previously described (19). Blood samples were collected, centrifuged at $3000 \mathrm{rpm}$ for 15 minutes and stored at $-20^{\circ} \mathrm{C}$ before they were analyzed.

Analytical methods

Serum total antioxidant capacity (TAC) level was determined as previously described (20). Serum alanine amino transferase (ALT) and aspartate amino transferase (AST) activities were determined colorimetrically (21). The level of uric acid was determined using Barham and Trinder method (22), while creatinine was measured according to Bartles and Bohmer method (23).

\section{Antihyperglycaemic effect}

The methanol extract of $P$. timorense bark was evaluated for the antihyperglycaemic activity using the method that was described previously (24).

\section{Statistical analysis}

One-way ANOVA was used to analyze the data. The result was considered statistically significant at $P$ value $<0.05$.

\section{Results}

Phytochemical screening

The results of phytochemical analysis of the bark of $P$. timorense revealed the presence of carbohydrate, terpenoids, coumarins, saponins flavonoids and tannins, while alkaloids were absent (Table 1).
HPLC analysis of flavonoids and phenolic compounds in $70 \%$ methanol extract of Pleiogynium timorense bark Fourteen flavonoidal compounds were identified representing $36.97 \mathrm{mg} / \mathrm{g}$ of the total content, the major flavonoid was quercetin $(5.31 \mathrm{mg} / \mathrm{g})$ followed by naringenin $(5.12 \mathrm{mg} / \mathrm{g})$. On the other hand, 16 phenolic compounds were identified representing $25.85 \mathrm{mg} / \mathrm{g}$ of the total content. The major phenolic compound was catechin $(4.56 \mathrm{mg} / \mathrm{g})$ followed by $\rho$-hydroxy benzoic acid (3.26 mg/g) (Table 2).

\section{Characterizations of compounds Compound 1}

Compound 1, (10 mg), was isolated as yellow powder with $\mathrm{R}_{\mathrm{f}}=0.31$ in n-butanol: acetic acid: water $(4: 1: 5, \mathrm{v} / \mathrm{v} / \mathrm{v})(\mathrm{S} 1)$ and 0.43 in water: glacial acetic acid $(85: 15, \mathrm{v} / \mathrm{v})(\mathrm{S} 2)$. Under UV; it gave purple color and upon exposure to ammonia and with $\mathrm{AlCl}_{3}$ the color changed to yellow. UV spectral data: $\lambda$ max nm in methanol; 257,358 , with sodium methoxide: 271, 411, with AlCl3: 273, 431, with AlCl3/HCl: 270, 402, with NaOAc: 273, 390, and with $\mathrm{NaOAc/H3BO3:}$ 260, 389.

${ }^{1} \mathrm{H}-\mathrm{NMR}$ spectral data in DMSO-d6: $6.6(\mathrm{~d}, \mathrm{~J}=8.3 \mathrm{~Hz}$, $\left.5^{-}\right), 6.3(\mathrm{~d}, \mathrm{~J}=2.2, \mathrm{H}-8), 7.47$ (dd, J = 2.1, $\left.8.3 \mathrm{~Hz}, \mathrm{H}-6^{-}\right), 6.1$ $(\mathrm{d}, \mathrm{J}=2.2 \mathrm{H}-6), 7.4\left(\mathrm{~d}, \mathrm{~J}=2.2 \mathrm{~Hz}, \mathrm{H}-2^{-}\right), 5.3(\mathrm{~d}, \mathrm{~J}=7.1 \mathrm{~Hz}$, $\mathrm{H}-1), 1.2(\mathrm{~d}, \mathrm{~J}=6.7 \mathrm{~Hz}, \mathrm{Me})$ and $4.2\left(\mathrm{~d}, \mathrm{~J}=1.4 \mathrm{~Hz}, \mathrm{H}-1^{--}\right)$.

\section{Compound 2}

Compound 2, (7 mg), was isolated as yellow amorphous powder with $\mathrm{R}_{\mathrm{f}}=0.55$ in S1 and 0.64 in S2. Under UV, it gave purple color which turned by ammonia to yellow. Acid hydrolysis gave quercetin (as aglycone) and rhamnose (as sugar). UV spectral data: $\lambda$ max $\mathrm{nm}$ in methanol; 257,352 , with $\mathrm{NaOMe}$ : 272, 391, with $\mathrm{AlCl} 3: 276$, 432, with $\mathrm{AlCl}_{3}$ / HCl: 272, 401, with NaOAc: 273, 373 and with NaOAc/ $\mathrm{H}_{3} \mathrm{BO}_{3}: 262,369 .{ }^{1} \mathrm{H}-\mathrm{NMR}$ spectral data in DMSO-d6: 6.3 $(\mathrm{d}, \mathrm{J}=2.4, \mathrm{H}-8), 6.13$ (d, J = 2.4, H-6), $6.84(\mathrm{~d}, \mathrm{~J}=8.9 \mathrm{~Hz}$, $\left.5^{-}\right), 7.25\left(\mathrm{~m}, \mathrm{H}-2\right.$ and $\left.\mathrm{H}-6^{-}\right), 0.77(\mathrm{~d}, \mathrm{~J}=6 \mathrm{~Hz}, \mathrm{Me})$ and 5.3 $\left(\mathrm{d}, \mathrm{J}=2.1 \mathrm{~Hz}, \mathrm{H}-1^{--}\right)$.

\section{Compound 3}

Compound 3, (9 mg), was isolated as yellow powder with $\mathrm{R}_{\mathrm{f}}=0.93$ in $\mathrm{S} 1$ and 0.15 in S2. It gave yellow color under UV light which was turned to yellow with ammonia vapor. UV spectral data: $\lambda$ max nm in methanol; 261, 367, with

Table 1. Results of phytochemical screening of the bark methanol extract of Pleiogynium timorense

\begin{tabular}{lc}
\hline Chemical constituents & Present (+) or absent (-) \\
\hline 1. Carbohydrate and/or glycosides & + \\
2. Coumarins & + \\
3. Saponins & + \\
4. Flavonoids & + \\
5. Sterols and/or triterpenes & + \\
6. Alkaloids and/or nitrogenous bases & - \\
7. Tannins & + \\
\hline
\end{tabular}


Table 2. HPLC analysis of flavonoids and phenolic compounds in $70 \%$ methanol extract of Pleiogynium timorense bark

\begin{tabular}{|c|c|c|c|}
\hline Flavonoids & Concentration (mg/100 g) & Phenolics & Concentration (mg/100 g) \\
\hline Apigenin & 241.32 & Caffeine & 73.23 \\
\hline Rhamentin & 351.66 & Shikimic acid & 14.33 \\
\hline Naringenin & 168.06 & Galloylquinic acid & 96.98 \\
\hline Kaempferol & 223.42 & Gallic acid & 315.32 \\
\hline Hespirtin & - & Pyrogallol & 284.89 \\
\hline Quercetin & 531.42 & Methyl gallate & 199.75 \\
\hline Apigenin -7-glucose & 045.32 & Protocatchuic acid & 73.56 \\
\hline Quercetrin & 452.16 & Ellagic acid & 88.92 \\
\hline Rutin & 413.23 & Vanillic acid & 17.09 \\
\hline Hesperidin & 091.46 & Coumaric acid & 69.89 \\
\hline Naringenin & 512.66 & Caffeic acid & 69.53 \\
\hline Apigenin-7-glucose & 210.42 & Catechin & 456.84 \\
\hline Apigenin-6-rhamnose-8-glucose & 125.87 & Cinnamic acid & 19.73 \\
\hline Apigenin-6-arabinose-8-galactose & 198.31 & Benzoic acid & - \\
\hline Acacetin neo rutinoside & - & Ferulic acid & - \\
\hline Acacetin-7-neo hesperside & - & $\rho$-Hydroxy benzoic acid & 326.34 \\
\hline \multirow[t]{2}{*}{ Kaempferol-3,7-dirhamnoside } & 132.15 & Catechol & 285.24 \\
\hline & & Chlorogenic acid & 193.87 \\
\hline
\end{tabular}

NaOMe: 273, 404, with $\mathrm{AlCl} 3: 273$, 445, with $\mathrm{AlCl} 3 / \mathrm{HCl}$ : 265, 432, with NaOAc: 273, 405 and with NaOAc/H3BO3: 262, 386. ${ }^{1} \mathrm{H}-\mathrm{NMR}$ spectral data in MeOD: 6.5 (d, J = 2.1, $\mathrm{H}-8), 6.93$ (d, J=Hz, 5), 6.17 (d, J = 2.1, H-6), 7.54 (d, J = $\left.2.2,8.5 \mathrm{~Hz}, \mathrm{H}-6^{-}\right)$and $7.73(\mathrm{~d}, \mathrm{~J}=2.1 \mathrm{~Hz}, \mathrm{H}-2)$.

\section{Compound 4}

Compound 4, (8 mg), was isolated as yellow powder with $\mathrm{R}_{\mathrm{f}}=0.66$ in S1 and 0.9 in S2. It gave dull yellow color under $\mathrm{UV}$, with ammonia vapor and with $\mathrm{AlCl} 3$. UV spectral data in methanol: 269, 365 with NaOMe: 277, 415, with AlCl3: 269,423 with $\mathrm{AlCl} 3 / \mathrm{HCl}: 268,423$, with $\mathrm{NaOAc}$ : 274, 385 and with NaOAc/H3BO3: 266, 370.

\section{Compound 5}

Compound 5, (13 mg), was isolated as white crystals with $\mathrm{R}_{\mathrm{f}}=0.6$ in methanol: chloroform (30:70) S 3. With vanillin sulphuric acid reagent, it gave strong pink color. ${ }^{1} \mathrm{H}-\mathrm{NMR}$ spectral data: 6.76 (H-5', d, J(H-5', H-6') $8.04 \mathrm{~Hz}), 6.87$ (H-2', d, J(H-2, H-6) $1.93 \mathrm{~Hz}), 6.03$ (H-8, d, J(H-8, H-6) $2.5 \mathrm{~Hz}), 5.88$ (H-6, d, J(H-6, H-8) $2.5 \mathrm{~Hz}), 2.92$ (H-4e, dd, J(H-4e, H-3a) $5.53 \mathrm{~Hz}, \mathrm{~J}(\mathrm{H} 4 \mathrm{e}, \mathrm{H}-4 \mathrm{a}) 16.12 \mathrm{~Hz}), 2.56$ (H4a, dd, (H-4a, H-3a) $8.52 \mathrm{~Hz}, \mathrm{~J}(\mathrm{H}-4 \mathrm{a}, \mathrm{H}-4 \mathrm{e}) 16.13 \mathrm{~Hz}$, $4.02(\mathrm{H}-3, \mathrm{~m}), \delta 4.54(\mathrm{H}-2, \mathrm{~d}, \mathrm{~J}(\mathrm{H}-2, \mathrm{H}-3 \mathrm{a}) 7.5 \mathrm{~Hz}), 6.75$ (H-6', dd, J(H-6', H-2) $1.96 \mathrm{~Hz}, \mathrm{~J}(\mathrm{H}-6$ ', H-5) $8.17 \mathrm{~Hz})$ and 8.03. ${ }^{13} \mathrm{C}-\mathrm{NMR}$ spectral data: 114.7 (C-2), 80.7 (C-2), 95.3 (C-8), 93.6 (C-6), $\delta 66.1$ (C-3), 27.4 (C-4), Peaks at $\delta$ of $99.3,130.8,144.3,144.5,155.2,156.3$, and 156.6 for other aromatic carbons.

\section{Compound 6}

Compound 6, (15 mg), was isolated as white amorphous powder with $\mathrm{R}_{\mathrm{f}}=0.69$ in $\mathrm{S} 1$ and 0.55 in $\mathrm{S} 2$, it gave violet color under short UV light. ${ }^{1} \mathrm{H}-\mathrm{NMR}$ spectral data of compound 6:7.09 (s, H-2, 6). ${ }^{13} \mathrm{C}-\mathrm{NMR}$ spectrum of compound 6: $\delta 169.18(\mathrm{C}=\mathrm{O}), 144.96$ for $(\mathrm{C} \mathrm{3}, 5), \delta 138.17$ (C-4), $\delta 120.76$ (C-1) and $\delta 108.7$ (C-2,6).

\section{Compound 7}

Compound 7, (15 mg), was isolated as brown needles with $\mathrm{R}_{\mathrm{f}}=0.85$ in $\mathrm{S} 1$ and 0.6 in $\mathrm{S} 2$, its melting point was $132-135^{\circ} \mathrm{C}$ and it gave violet color under short UV light, $R_{\mathrm{f}}$ values $=0.85$ in S1 and 0.6 in S2. EI-MS $m / z: 126(100$, $\mathrm{M}+$ ). ${ }^{1} \mathrm{H}-\mathrm{NMR}$ spectral data in DMSO-d6: $\delta: 6.43$ (t, H-5) and $6.26(\mathrm{~d}, J=8.1,2 \mathrm{H}, \mathrm{H}-4$ and 6$) .{ }^{13} \mathrm{C}-\mathrm{NMR}$ spectral data in DMSO-d6: $\delta$ : 119.5 (C-5), 107.6 (C-4, C-6), 133.5 (C-2) and 147.07 (C-1, 3).

The structures of the isolated compounds are illustrated in Figure 1.

The cytotoxic activity

The cytotoxic activity of $70 \%$ methanol extract of $P$. timorense bark was assessed in vitro against HFB-4, MCF7, HepG2 and HCT116 cell lines in comparison with doxorubicin (Table 3 ). The results showed cytotoxic activity of the extract with $\mathrm{IC}_{50}$ of $42.89,23.45,4.39$ and $10.78(\mu \mathrm{g} / \mathrm{mL})$, respectively, by comparing these results with that of doxorubicin $\mathrm{IC}_{50}(3.52,3.12,3.86$ and $4.49 \mu \mathrm{g} /$ $\mathrm{mL}$, respectively). It was found that the methanol extract possessed a potent cytotoxicity against HepG2 $\left(\mathrm{IC}_{50}=4.39\right.$ $\mu \mathrm{g} / \mathrm{mL})$.

On the other hand, Table 4 shows in vitro cytotoxic activity of the isolated compounds against HepG2 cell line in comparison with doxorubicin. Rutin, quercetrin, quercetin, kaempferol, catechin, gallic acid and pyrogallol had cytotoxic activities with $\mathrm{IC}_{5}=15.7,18.8,25.5,29.3,6.4$, 9.6 and 12.3 , respectively.

Acute toxicity study

$\mathrm{LD}_{50}$ was found to be $4.8 \mathrm{~g} / \mathrm{kg}$ body weight, this relatively 
<smiles>Oc1cccc(O)c1O</smiles><smiles>Oc1cc(O)c2c(c1)OC(c1ccc(O)c(O)c1)C(O)C2</smiles>
Catechin

Pyrogallol<smiles>O=c1c(O)c(-c2ccc(O)c(O)c2)oc2cc(O)cc(O)c12</smiles>

Quercetin

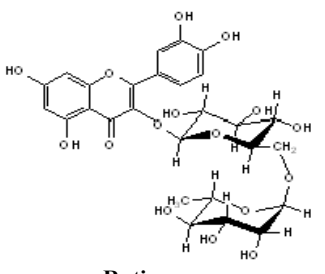

Rutin

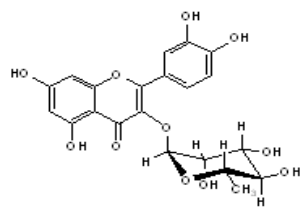

Quercetrin
Figure 1. Chemical structures of the isolated compounds.

high $\mathrm{LD}_{50}$ indicates low toxicity.

Antioxidant, hepato-protective and renal function protective effects

TAC was significantly increased in the two doses of the bark extract compared with that of the control group. Liver enzymes (ALT and AST) were significantly decreased in the two doses of the bark extract compared with both control and silymarin groups (Table 5). Creatinine and uric acid concentrations were significantly decreased in the two doses of the bark extract compared with control and silymarin treatment groups (Table 5).

$\mathrm{CCl}_{4}$ treatment showed a significant decrease in TAC serum content (Table 6). The two doses of the bark extract showed significant increase in TAC level in carbon tetrachloride hepatic damaged rats compared with carbon tetrachloride treatment alone. Liver enzymes were significantly increased in $\mathrm{CCl}_{4}$-toxicated groups. The two doses of the bark extract showed a significant decrease in the elevated level of liver enzymes that was caused by $\mathrm{CCl}_{4}$. Uric acid and creatinine were significantly elevated by $\mathrm{CCl}_{4}$ treatment. The bark extract in the two dose levels showed a significant decrease in creatinine and uric acid values compared with both control and silymarin groups (Table 6).

\section{Antihyperglycaemic test}

Serum glucose level of the rats was significantly decreased by treating with the two doses of the bark extract in a dose-dependent manner (Table 7).

\section{Discussion}

Phytochemical screening of the bark of $P$. timorense revealed the presence of various phytoconstituents which are responsible for the bioactivities of the plant. So. the current study attempted to discover the relation between the phytoconstituents of $P$. timorense bark and the tested bioactivities. HPLC analysis confirmed the presence of extensive number of phenolic compounds with reasonable amounts. Recently, many studies have examined the cytotoxicity, antioxidant and antihyperglycemic activities of phenolic compounds (25-27). Chromatographic examination of the $70 \%$ methanol extract of $P$. timorense bark resulted in the isolation and identification of seven compounds for the first time from the bark.

UV spectrum of compound 1 gave a bathochromic shift in band $\mathrm{I}$ in addition of $\mathrm{NaOMe}$ with an increase in intensity which indicated the presence of the free hydroxyl group at 4'. Band II showed bathochromic shift on addition of sodium acetate which indicated the presence of free hydroxyl group at position 7 . The hypsochromic shift with $\mathrm{HCl}$ after addition of $\mathrm{AlCl}_{3}$ confirmed the presence of orthodihydroxy pattern in ring B. Acid hydrolysis showed that the quercetin was aglycone, while sugars were rhamnose and glucose. ${ }^{1} \mathrm{H}-\mathrm{NMR}$ spectrum of compound 1 showed a doublet at $\delta 6.6(\mathrm{~J}=8.3 \mathrm{~Hz})$ for $\mathrm{H}-5^{\prime}$, a doublet

Table 3. Cytotoxic activity of $70 \%$ methanol extract of Pleiogynium timorense bark and Doxorubicin against cultured different cell lines

\begin{tabular}{lcccc}
\hline & IC $_{50}(\mu \mathrm{g} / \mathrm{mL})$ & & & \\
\hline Human Cell line & HFB-4 & MCF7 & HepG2 & HCT116 \\
\hline $70 \%$ methanol extract of Pleiogynium timorense bark & 42.89 & 23.45 & 4.39 & 3.12 \\
Doxorubicin & 3.52 & 3.86 & 4.49 \\
\hline
\end{tabular}

$\mathrm{IC}_{50}$ : The half maximal inhibitory concentration, HFB-4: normal melanocytes, MCF-7: human breast carcinoma, HepG2: human hepatocellular liver carcinoma, HCT116: human colon carcinoma.

Table 4. The cytotoxicity of the isolated compounds from methanol extract of Pleiogynium timorense bark against HepG2

\begin{tabular}{cccccccccc}
\hline & \multicolumn{9}{c}{ Compounds } \\
\hline & Rutin & Quercitrin & Quercetin & Kaempferol & Catechin & Gallic acid & Pyrogallol & Doxorubicin \\
\hline $\mathrm{IC}_{50}(\mu \mathrm{g} / \mathrm{mL})$ & 15.7 & 18.8 & 25.5 & 29.3 & 6.4 & 9.6 & 12.3 & 3.86 & \\
\hline
\end{tabular}

$\mathrm{IC}_{50}$ : The half maximal inhibitory concentration. 
Phytoconstituents and bioactivities of Pleiogynium timorense Bark

Table 5. The activity of Pleiogynium timorense (DC.) Leenh. methanol extract of the bark as antioxidant and hepato-renal protective remedy in normal rats

\begin{tabular}{|c|c|c|c|c|c|}
\hline Groups & Uric acid & Creatinine & AST & ALT & TAC \\
\hline Control & $1.25 \pm 0.014$ & $0.46 \pm 0.016$ & $46 \pm 1.05$ & $26.2 \pm 1.45$ & $1.23 \pm 0.025$ \\
\hline Silymarin & $1.23 \pm 0.08^{\mathrm{a}}$ & $0.37 \pm 0.05^{a}$ & $37 \pm 2.15^{\mathrm{a}}$ & $21.2 \pm 1.68^{\mathrm{a}}$ & $1.58 \pm 0.02^{a}$ \\
\hline Bark 150 mg/kg & $1.20 \pm 0.019^{b}$ & $0.34 \pm 0.012^{\mathrm{a}}$ & $40.42 \pm 2.1^{\mathrm{ab}}$ & $23.3 \pm 0.92^{b}$ & $1.43 \pm 0.02^{\mathrm{ab}}$ \\
\hline Bark 300 mg/kg & $1.18 \pm 0.0^{\mathrm{ab}}$ & $0.31 \pm 0.035^{a}$ & $38.33 \pm 2.83^{b}$ & $20.7 \pm 0.53^{\mathrm{a}}$ & $1.53 \pm 0.02^{\mathrm{ab}}$ \\
\hline
\end{tabular}

AST: aspartate amino transferase, ALT: alanine amino transferase, TAC: serum total antioxidant capacity.

${ }^{\mathrm{a}} P \leq 0.05$ compared to control group; ${ }^{\mathrm{b}} P \leq 0.05$ compared to silymarin treatment group.

Table 6. The activity of Pleiogynium timorense (DC.) Leenh. methanol extract of the bark as antioxidant and hepato-renal protective remedy in hepatic damage

\begin{tabular}{|c|c|c|c|c|c|}
\hline Groups & Uric acid & Creatinine & AST & ALT & TAC \\
\hline CCL4 & $2.45 \pm 0.09$ & $1.37 \pm 0.09$ & $88.7 \pm 2.9$ & $46.7 \pm 1.14$ & $0.86 \pm 0.017$ \\
\hline Silymarin & $1.74 \pm 0.09^{a}$ & $0.74 \pm 0.09^{a}$ & $67.5 \pm 0.93^{\mathrm{a}}$ & $25.9 \pm 1.34^{\mathrm{a}}$ & $1.23 \pm 0.01^{\mathrm{a}}$ \\
\hline Bark 150 mg/kg & $1.70 \pm 0.07^{\mathrm{ab}}$ & $0.77 \pm 0.09^{a}$ & $68.2 \pm 1.64^{b}$ & $32.4 \pm 1.25^{\mathrm{ab}}$ & $1.11 \pm 0.01^{\mathrm{ab}}$ \\
\hline Bark 300 mg/kg & $1.67 \pm 0.09^{b}$ & $0.73 \pm 0.07^{\mathrm{ab}}$ & $69.6 \pm 1.35^{a}$ & $34.9 \pm 0.89^{b}$ & $1.22 \pm 0.02^{\mathrm{ab}}$ \\
\hline
\end{tabular}

CCL4, carbon tetra chloride; AST: aspartate amino transferase, ALT: alanine amino transferase, TAC: serum total antioxidant capacity. a $P \leq 0.05$ compared to CCL4 group; ${ }^{b} P \leq 0.05$ compared to silymarin treatment group.

Table 7. Antihyperglycemic effect of $70 \%$ methanol extract of the bark of Pleiogynium timorense (DC.) Leenh

\begin{tabular}{|c|c|c|c|c|c|}
\hline Groups & 0 -time & $15 \mathrm{~min}$ & $30 \mathrm{~min}$ & $45 \mathrm{~min}$ & $60 \mathrm{~min}$ \\
\hline Control & $2.33 \pm 0.015$ & $2.37 \pm 0.022$ & $2.43 \pm 0.017$ & $2.55 \pm 0.018$ & $2.64 \pm 0.014$ \\
\hline Control positive & $2.83 \pm 0.03$ & $7.83 \pm 0.061^{\mathrm{a}}$ & $8.05 \pm 0.061^{\mathrm{a}}$ & $10.6 \pm 0.035^{a}$ & $11.77 \pm 0.01^{\mathrm{a}}$ \\
\hline Bark 150 mg/kg & $2.65 \pm 0.025$ & $5.09 \pm 0.021^{b}$ & $5.80 \pm 0.011$ & $4.65 \pm 0.03^{\mathrm{ab}}$ & $4.52 \pm 0.02^{\mathrm{ab}}$ \\
\hline Bark 300 mg/kg & $2.47 \pm 0.042$ & $4.1 \pm 0.011^{\mathrm{a}}$ & $4.54 \pm 0.033^{a}$ & $4.43 \pm 0.04^{\mathrm{ab}}$ & $4.33 \pm 0.32^{\mathrm{ab}}$ \\
\hline
\end{tabular}

${ }^{\mathrm{a}} P \leq 0.05$ compared to control group; ${ }^{\mathrm{b}} P \leq 0.05$ compared to positive control group.

of doublet at $\delta 7.47(J=2.1,8.3 \mathrm{~Hz})$ for $\mathrm{H}-6^{\prime}$. It showed a doublet at $\delta 7.4(J=2.2 \mathrm{~Hz})$ for $\mathrm{H}-2^{\prime}$, while $\mathrm{H}-6$ and $\mathrm{H}-8$ appeared at $\delta 6.1$ and $\delta 6.3$, respectively as meta coupling protons. The anomeric glucose proton $\mathrm{H}-1^{\prime \prime}$ showed doublet at $\delta 5.3$ with $\beta$ - linkage, while those at $\delta 4.2$ and at $\delta 1.2$ for rhamnose with $\alpha$ - linkage. These data were confirmed with the data which were reported for rutin (28).

UV spectrum of compound 2 gave a bathochromic shift in band I in addition of $\mathrm{NaOMe}$ with a marked increase in the intensity which confirmed free hydroxyl group at 4 . On addition of sodium acetate, band II showed a bathochromic shift which indicated the presence of free hydroxyl group at position 7. With addition of $\mathrm{HCl}$ after $\mathrm{AlCl}_{3}$, the spectrum showed hypsochromic shift that confirmed the presence of orthodihydroxy pattern in ring B. ${ }^{1} \mathrm{H}-\mathrm{NMR}$ spectrum of compound 2 showed doublet for $\mathrm{H}-5^{\prime}$ at $\delta 6.84(\mathrm{~J}=\delta 8.9 \mathrm{~Hz})$ as a result of ortho-coupling with H-6, and multiplet at $\delta 7.25$ for H-2' and H-6', and for $\mathrm{H}-8$ and $\mathrm{H}-6$, peaks at $\delta 6.3$ and 6.1 appeared, respectively with $\mathrm{J}=2.4 \mathrm{~Hz}$ due to meta coupling. Anomeric proton of the rhamnose showed signal at $\delta 5.3$ with $\mathrm{J}=2.1 \mathrm{~Hz}$ due to a-configuration and rhamnose showed doublet at $\delta 0.77$ with $\mathrm{J}=6 \mathrm{~Hz}$ for its methyl group. After acid hydrolysis, the sugar showed to be rhamnose while aglycone was quercetin. These data were confirmed with the data which were reported for quercitrin (28).

For compound 3, on addition of sodium methoxide, band I showed a bathochromic shift with a marked increase in intensity which indicated the presence of free hydroxyl group at 4. On addition of sodium acetate, band II showed a bathochromic shift that confirmed that hydroxyl group at position 7 was free. The presence of free hydroxyl group at position 5 was indicated after addition of $\mathrm{AlCl} 3 / \mathrm{HCl}$ due to bathochromic shift in band Ia when it was compared with that in methanol. The presence of ortho-dihydroxyl pattern at ring-B was indicated after addition of sodium acetate with boric acid, as band I showed a bathochromic shift when it was compared with that in methanol. ${ }^{1} \mathrm{H}-\mathrm{NMR}$ spectrum of compound 3 showed doublet at $\delta 7.73$ for $\mathrm{H}-2$ ' with $\mathrm{J}=2.1 \mathrm{~Hz}$ for metacoupling with proton at $\mathrm{H}-6$ ' that showed signal at $\delta 7.54$. For $\mathrm{H}-5$, it showed a doublet at $\delta 6.93$ with $\mathrm{J}=8.1 \mathrm{~Hz}$ that showed ortho-coupling with H6' The two meta-coupling protons for $\mathrm{H}-8$ and $\mathrm{H}-6$ appeared at $\delta 6.5$ and $\delta 6.17$ with $\mathrm{J}=2.1 \mathrm{~Hz}$. These data were confirmed with the data which were reported for quercetin (28).

The UV spectrum of compound 4 showed a bathochromic shift in band I on addition of $\mathrm{NaOMe}$ and the intensity was increased which proved that hydroxyl group at position 4' was free. Band II showed a bathochromic shift on addition of sodium acetate that confirmed the 
presence of free hydroxyl group at position 7. The absence of orthodihydroxy pattern in ring B was confirmed by the absence of hypsochromic shift with $\mathrm{AlCl} / \mathrm{HCl}$. These data were confirmed with the data which were reported for kaempferol (28).

${ }^{1} \mathrm{H}-\mathrm{NMR}$ spectrum of compound 5 gave doublet of doublet peak at $\delta 6.75$ for proton $\mathrm{H}-6$ with ortho-coupling with $\mathrm{H}-5^{\prime}$ and meta-coupling with $\mathrm{H}-2^{\prime}$, doublet peak at $\delta 5.88$ for proton $\mathrm{H}-6$ which formed with $\mathrm{H}-8$ meta coupling, doublet peak at $\delta 6.79$ for proton $\mathrm{H}-5$ with ortho-coupling with $\mathrm{H}^{\prime}$, doublet peak at $\delta 6.87$ for proton H-2' with meta-coupling with H-6. H-8 showed peak at $\delta 6.03$ as doublet with meta coupling with $\mathrm{H}-6$, while proton $\mathrm{H}-4 \mathrm{e}$ gave peak at $\delta 2.92$, proton $\mathrm{H}-4$ a showed peak at $\delta 2.56$, multiple at $\delta 4.02$ for $\mathrm{H}-3$, doublet peak at $\delta 4.54$ as for $\mathrm{H}-2$ and multiple peaks at $\delta 8.03$ for phenolic protons. ${ }^{13} \mathrm{C}$-NMR spectrum of compound 5 gave peak at $\delta 93.6$ for carbon (C-6), (C-8) showed peak at $\delta$ 95.3, peak at $\delta 80.7$ for carbon (C-2), peak at $\delta 66.1$ for carbon (C-3), peak at $\delta 27.4$ for carbon (C-4) and showed peaks at $\delta 156.6,156.3,155.2,130.8,144.85,144.3$ and 99.3 for other aromatic carbons. By comparing these data with the previously published data (29), compound 5 was identified as catechin.

${ }^{1} \mathrm{H}-\mathrm{NMR}$ spectrum of compound 6 gave a sharp singlet peak at $\delta 7.09 \mathrm{ppm}$ for two protons $\mathrm{H}-2,6 .{ }^{13} \mathrm{C}-\mathrm{NMR}$ spectrum of compound 6 showed the carbon of carbonyl of carboxylic group at $\delta 169.18, \delta 144.96$ for C-3,5, $\delta$ 138.17 for C-4, $\delta 120.76$ for C-1 and $\delta 108.7$ for C-2,6. So, compound 6 was identified as gallic acid.

${ }^{1} \mathrm{H}-\mathrm{NMR}$ spectrum of compound 7 showed a triplet peak at $\delta$ : 6.43 for $\mathrm{H}-5$ and a doublet peak at 6.26 for two protons $\mathrm{H}-4,6 .{ }^{13} \mathrm{C}-\mathrm{NMR}$ spectrum of compound 7 gave a peak at $\delta: 107.6$ for C-4 \& C-6, peak at 119.5 for C-5, peak at 133.5 for C-2 and peak at 147.07 for C-1,3. By comparing with the previously published data (30), compound 7 was identified as pyrogallol.

As the antioxidant activity of the isolated compounds were previously reported $(31,32)$, so they played an important role in appearing the bioactivities of the extract. Recently, dichloromethane extract of the bark showed a significant activity against the A2780 human ovarian cancer cell line due to the presence of three new trihydroxy alkylcyclohexenones which were isolated from this extract (10). This reported research is the first study regarding the bark of $P$. timorense. Therefore, we aimed to continue the study of the cytotoxic effect of the methanol extracts and the isolated compounds against different cell lines. The methanol extract showed a promising cytotoxic activity against HepG 2 cell line $\left(\mathrm{IC}_{50}=4.39 \mu \mathrm{g} / \mathrm{mL}\right)$ comparing with that of Doxorubicin $\left(\mathrm{IC}_{50}=3.86 \mu \mathrm{g} / \mathrm{mL}\right)$. We expected that this potent activity might be due the phenolic compounds. So, the cytotoxic activity of the isolated compounds was assessed in vitro against HepG2 cell line in comparison with Doxorubicin. Both catechin and gallic acid possessed moderate cytotoxic activity against HepG2 cell line ( $\mathrm{IC}_{50}$ $=6.4, \& 9.6 \mu \mathrm{g} / \mathrm{mL}$, respectively, by comparing with Doxorubicin $\left(\mathrm{IC}_{50}=3.86 \mu \mathrm{g} / \mathrm{mL}\right)$. We can conclude that the methanol extract of $P$. timorense bark has more potent in vitro cytotoxicity against $\mathrm{HepG} 2$ cell line $\left(\mathrm{IC}_{50}=4.39\right.$ $\mu \mathrm{g} / \mathrm{mL}$ ) than that of the isolated compounds. This might be due to the synergistic effect of the phenolic contents in the methanol extract which play a vital role in the bioactivities.

The two doses of the $70 \%$ methanol extract of $P$. timorense bark $(150 \& 300 \mathrm{mg} / \mathrm{kg})$ showed significant increase in TAC and significant decrease in the liver enzymes (ALT\& AST), urea and creatinine levels compared with control and silymarin groups in both normal and hepatotoxic groups. Moreover, the two doses of the $70 \%$ methanol extract significantly decreased the blood glucose level. These results revealed that the $70 \%$ methanol extract of P. timorense bark had promising antioxidant, hepatorenal protective and antihyperglycemic effects, and the phytoconstituents in the methanol extract were responsible for these activities.

\section{Conclusion}

The present study revealed the positive effects of methanol extract of the bark of $P$. timorense (DC.) Leenh for use as antioxidant, hepatorenal protective, antihyperglycemic and anticancer. Detailed information on the phytoconstituents and the above mentioned biological activities were discussed in this research.

\section{Acknowledgments}

We acknowledge to the National Research Centre and Faculty of Pharmacy Nahda University, Egypt and College of Pharmacy, Jouf University, Sakakah, Saudi Arabia for using laboratory instruments in doing research.

\section{Authors' contribution}

All authors conceived, designed and performed the experiment and analyzed the data; GFAR wrote and revised the paper; all authors read and confirmed publication of the paper.

\section{Conflict of interests}

The authors have no conflict of interests to declare.

\section{Ethical considerations}

Ethical issues (including plagiarism, misconduct, data fabrication, falsification, double publication or submission, redundancy) have been completely observed by the authors. The handling with animals were complied with the ethical guidelines of the Medical Ethical Committee of the National Research Centre in Egypt and were in accordance with the guidelines of the International Association for the Study of Pain Committee for Research and Ethical Issues. 


\section{Funding/Support}

This research had no financial support.

\section{References}

1. Quattrocchi U. CRC World Dictionary of Plant Names, Vol M-Q. New York, Washington DC: CRC Press; 1999; 2107.

2. Rozefelds A, Dettmann M, Clifford T, Hocknull S, Newman N, Godthelp H, et al. Traditional and computed tomographic (CT) techniques link modern and Cenozoic fruits of Pleiogynium (Anacardiaceae) from Australia. Alcheringa: An Australasian Journal of Palaeontology. 2015;39(1):24-39. doi: 10.1080/03115518.2014.951916.

3. Cavalcanti SBT, Teles HL, Silva DHS, Furlan M, Young MCM, Bolzani VS. New tetra-acetylated oligosaccharide diterpene from Cupania vernalis. J Braz Chem Soc. 2001;12(3):413-6. doi: 10.1590/S0103-50532001000300014.

4. Everett TH. The New York Botanical Garden Illustrated Encyclopedia of Horticulture. Vol. 8. New York, London: Garland; 1981. p. 2721

5. El-Fiki NM, Ahmed FI. Phytochemical study of Pleiogynium solandri (Benth.) Engl J Pharm Sci. 1999;24:38-50.

6. Al Sayed E, Martiskainen O, Sinkkonen J, Pihiaja K, Ayoub $\mathrm{N}$, Singab AE, et al. Chemical composition and bioactivity of Pleiogynium timorense (Anacardiaceae). Nat Prod Commun. 2010;5(4):545-50.

7. Netzel M, Netzel G, Tian Q, Schwartz S, Konczak I. Native Australian fruits--a novel source of antioxidants for food. Innov Food Sci Emerg Technol. 2007;8(3):339-46. doi: 10.1016/j.ifset.2007.03.007.

8. Said A, Abuotabl EA, Abdel Raoof GF, Huefner A, Nada SA. Phenolic contents and bioactivities of pericarp and seeds of Pleiogynium solandri (Benth.) Engl. (Anacardiaceae). Iran J Basic Med Sci. 2015;18(2):164-71.

9. Said A, Aboutabl EA, Hussein AA, Abdel Raoof GF. The composition of the lipoidal matter of the seeds of Pleiogynium timorense (DC.) Leenh. Egypt Pharm J. 2015;14(1):65-8. doi: 10.4103/1687-4315.154725.

10. Eaton AL, Rakotondraibe LH, Brodie PJ, Goetz M, Kingston DG. Antiproliferative Trihydroxyalkylcyclohexenones from Pleiogynium timoriense. J Nat Prod. 2015;78(7):1752-5. doi: 10.1021/acs.jnatprod.5b00119.

11. Said A, Aboutabl EA, Abdel Raoof GF. Identification of Constituents from Pleiogynium timorense (Dc.) Leenh Pericarp and Seeds Using High-Performance Liquid Chromatography with Electrospray Ionization Mass Spectrometry. AASCIT J Chem. 2017;3(4):30-36.

12. Said A, Omer EA, El Gendy MAM, Abdel Raoof GF, Abd EL-Kader AE, Fouad R. Volatile constituents and cytotoxic activity of the fruits of Pleiogynium timorense (Dc.) Leenh. J Mater Environ Sci. 2018;9(8):2274-9.

13. Harbone JB. Phytochemical methods: a guide to modern techniques of plant analysis. London: Chapman \& Hall; 1973. p. 49.

14. Sofowora A. Medicinal plants and traditional medicine in Africa. Ibadan, Nigeria: Spectrum Books Ltd; 1993. p. 289.

15. Mattila P, Astola J, Kumpulainen J. Determination of flavonoids in plant material by HPLC with diode-array and electro-array detections. J Agric Food Chem. 2000;48(12):5834-41. doi: 10.1021/jf000661f.

16. Goupy P, Hugues M, Boivin P, Amiot MJ. Antioxidant composition and activity of barley (Hordeum vulgare) and malt extracts and of isolated phenolic compounds. J Sci Food Agric. 1999;79(12):1625-34. doi: 10.1002/(sici)10970010(199909)79:12<1625::aid-jsfa411>3.0.co;2-8
17. Skehan P, Storeng R, Scudiero D, Monks A, McMahon J, Vistica $D$, et al. New colorimetric cytotoxicity assay for anticancerdrug screening. J Natl Cancer Inst. 1990;82(13):1107-12. doi: 10.1093/jnci/82.13.1107.

18. Chinedu E, Arome D, Ameh FS. A new method for determining acute toxicity in animal models. Toxicol Int. 2013;20(3):224-6. doi: 10.4103/0971-6580.121674.

19. Cocchetto DM, Bjornsson TD. Methods for vascular access and collection of body fluids from the laboratory rat. J Pharm Sci. 1983;72(5):465-92. doi: 10.1002/jps.2600720503.

20. Koracevic D, Koracevic G, Djordjevic V, Andrejevic S, Cosic $\mathrm{V}$. Method for the measurement of antioxidant activity in human fluids. J Clin Pathol. 2001;54(5):356-61. doi: 10.1136/ jcp.54.5.356.

21. Huang B, Ban X, He J, Tong J, Tian J, Wang Y. Hepatoprotective and antioxidant activity of ethanolic extracts of edible lotus (Nelumbo nucifera Gaertn.) leaves. Food Chem. 2010;120(3):873-8. doi: 10.1016/j.foodchem.2009.11.020.

22. Barham D, Trinder P. An improved colour reagent for the determination of blood glucose by the oxidase system. Analyst. 1972;97(151):142-5. doi: 10.1039/an9729700142.

23. Bartels H, Bohmer M, Heierli C. [Serum creatinine determination without protein precipitation]. Clin Chim Acta. 1972;37:193-7. doi: 10.1016/0009-8981(72)90432-9.

24. Yaro AH, Aliyu M, Borodo SB, Nazifi AB. Antihyperglycaemic and antihyperlipidaemic activities of ethanol leaf extract of Eleusine coracana (Linn.) Gaertn. in alloxan-Induced hyperglycaemic rats. J Appl Pharm Sci. 2018;8(7):28-32. doi: 10.7324/JAPS.2018.8705.

25. Nandi S, Vracko M, Bagchi MC. Anticancer activity of selected phenolic compounds: QSAR studies using ridge regression and neural networks. Chem Biol Drug Des. 2007;70(5):42436. doi: 10.1111/j.1747-0285.2007.00575.x.

26. Bendaif H, Melhaoui A, Bouyanzer A, Hammouti B, El Ouadi Y. The study of the aqueous extract of leaves of Pancratium foetidum Pom as: characterization of polyphenols, flavonoids, antioxidant activities and ecofriendly corrosion inhibitor. J Mater Environ Sci. 2017;8(12):4475-86.

27. El-Sherei MM, Ragheb AY, Mosharrafa SA, Marzouk MM, Kassem MES, Saleh NAM. Pterygota alata (Roxb.) R. Br.: chemical constituents, anti-hyperglycemic effect and anti-oxidative stress in alloxan-induced diabetic rats. J Mater Environ Sci. 2018;9(1):245-55. doi: 10.26872/ jmes.2018.9.1.28.

28. Mabry TJ, Markham KR, Thomas MB. The systematic identification of flavonoids. New York: Springer-Verlag; 1970. p. 3371-8.

29. Hye A, Taher MA, Ali MY, Ali MU, Zaman S. Isolation of (+)-catechin from Acacia catechu (Cutch Tree) by a convenient method. J Sci Res. 2009;1(2):300-5. doi: 10.3329/ jsr.v1i2.1635.

30. Lu CH, Li YY, Li LJ, Liang LY, Shen YM. Anti-inflammatory activities of fractions from Geranium nepalense and related polyphenols. Drug Discov Ther. 2012;6(4):194-7.

31. Sang S, Tian S, Wang H, Stark RE, Rosen RT, Yang CS, et al. Chemical studies of the antioxidant mechanism of tea catechins: radical reaction products of epicatechin with peroxyl radicals. Bioorg Med Chem. 2003;11(16):3371-8. doi: 10.1016/s0968-0896(03)00367-5.

32. Sano M, Yoshida R, Degawa M, Miyase T, Yoshino K. Determination of peroxyl radical scavenging activity of flavonoids and plant extracts using an automatic potentiometric titrator. J Agric Food Chem. 2003;51(10):29126. doi: $10.1021 /$ jf0211276. 